\title{
Using movements, genetics and trophic ecology to differentiate inshore from offshore aggregations of humpback whales in the Gulf of Alaska
}

\author{
Briana H. Witteveen ${ }^{1, *}$, Jan M. Straley ${ }^{2}$, Ellen Chenoweth ${ }^{2}$, C. Scott Baker ${ }^{3}$, \\ Jay Barlow ${ }^{4}$, Craig Matkin ${ }^{5}$, Christine M. Gabriele ${ }^{6}$, Janet Neilson $^{6}$, Debbie Steel ${ }^{3}$, \\ Olga von Ziegesar ${ }^{7}$, Alexander G. Andrews ${ }^{8}$, Amy Hirons ${ }^{9}$ \\ ${ }^{1}$ University of Alaska Fairbanks, Sea Grant Marine Advisory Program, Kodiak, 118 Trident Way, Kodiak, Alaska 99615, USA \\ ${ }^{2}$ University of Alaska Southeast, Sitka Campus, 1332 Seward Avenue, Sitka, Alaska 99835, USA \\ ${ }^{3}$ Hatfield Marine Science Center, Oregon State University, 2030 SE Marine Science Drive, Newport, \\ Oregon 97365-5229, USA \\ ${ }^{4}$ Southwest Fisheries Science Center, National Marine Fisheries Service, 3333 North Torrey Pines Court, \\ La Jolla, California 92037-1022, USA \\ ${ }^{5}$ North Gulf Oceanic Society, PO Box 15244, Homer, Alaska 99603, USA \\ ${ }^{6}$ Glacier Bay National Park and Preserve, PO Box 140, Gustavus, Alaska 99826, USA \\ ${ }^{7}$ Eye of the Whale, PO Box 15191, Fritz Creek, Alaska 99603, USA \\ ${ }^{8}$ NOAA Fisheries Auke Bay Laboratories, 17109 Lena Point Loop Road, Juneau, Alaska 99801, USA \\ ${ }^{9}$ Nova Southeastern University, 8000 North Ocean Drive, Dania Beach, Florida 33004-3078, USA
}

\begin{abstract}
Humpback whales Megaptera novaeangliae have been studied in the coastal waters of the Gulf of Alaska (GOA) since the late 1960s, but information about whales foraging offshore is limited. A large-scale collaborative project (SPLASH) provided opportunities to study humpback whales in both inshore and offshore habitats. Using identification photographs and biopsy samples, we explored individual movements, the distribution of mitochondrial (mtDNA) haplotypes, and trophic levels for humpback whales within 3 regions (Kodiak, KOD; Prince William Sound, PWS; and southeastern Alaska, SEAK) of the GOA to determine whether inshore and offshore aggregations of humpback whales are distinct. Each region was divided into inshore and offshore habitats, creating 6 subregions for comparison. Results documenting 2136 individual whales showed that movement within the study area was most frequent between inshore and offshore subregions within a region. In general, movement between regions was minimal. Tissue samples of 483 humpback whales included 15 mtDNA haplotypes. Pairwise chi-squared tests showed haplotype differences between subregions, but inshore PWS was the only subregion with a haplotype composition significantly different than all other subregions. Trophic levels, as inferred from stable nitrogen isotope ratios, were significantly different among subregions, ranging from 3.4 to 4.5 . Pairwise comparisons showed that inshore PWS was again the only subregion that significantly differed from all others. Results suggest that the combined inshore and offshore habitats for KOD and the inshore and offshore habitats for SEAK should each be considered as single regional feeding aggregations, while inshore PWS may represent a separate aggregation from PWS offshore.
\end{abstract}

KEY WORDS: Humpback whale 'Megaptera novaeangliae ' Gulf of Alaska ' mtDNA · Haplotype Trophic level · Movement 


\section{INTRODUCTION}

The humpback whale Megaptera novaeangliae is a cosmopolitan species that undergoes extensive seasonal migrations. In the North Pacific, humpback whales migrate from low-latitude breeding and calving grounds to geographically distinct aggregations on higher-latitude feeding grounds. While a very small degree of interchange has been documented, these feeding aggregations are generally isolated from one another. This segregation has been attributed to the cultural transmission of fidelity to a feeding ground as a result of a calf's early maternal experience (Baker et al. 1990). This maternally directed fidelity results in a sorting of individual whales onto regional feeding grounds, which are characterized by differences in the rates of return by naturally marked individuals and frequencies of mitochondrial DNA (mtDNA) haplotypes within and between aggregations (Baker et al. 1998, Calambokidis et al. 2001). Despite the discreteness of feeding aggregations, only 3 stocks of humpback whales are defined within the North Pacific: the eastern, central, and western North Pacific stocks (Allen \& Angliss 2010). The eastern stock includes whales that feed in waters from California (USA) to southern British Columbia (Canada) and migrate to coastal Central America and Mexico for breeding. The central stock consists of whales that feed in northern British Columbia, throughout the Gulf of Alaska (GOA), and Bering Sea and winter around the Hawaiian Islands. Finally, the western stock feeds in the waters of the Russian Far East, the western Bering Sea, and western Aleutian Islands and winters near Asia.

Since the 1960s, several feeding aggregations assigned to the central stock within the inshore coastal waters of the GOA have been the focus of research directed at regional populations, including southeastern Alaska, Prince William Sound, Kodiak Island, and the Shumagin Islands. These studies are conducted from cost-effective platforms such as skiffs or smaller vessels by researchers who often live in communities close to their study areas. Results from these studies have shown the benefit of long-term research effort by providing estimates of abundance, life history parameters, and insights into the structure of feeding aggregations (Straley et al. 1994, 2002, 2009, Waite et al. 1999, von Ziegesar et al. 2001, Witteveen et al. 2004, 2007 , 2008). Additionally, using stable nitrogen isotope ratios $\left(\delta^{15} \mathrm{~N}\right)$, regional differences in trophic levels have been shown, suggesting that these regional feeding aggregations may be targeting different prey resources (Witteveen et al. 2009a, 2011).

Difficulty working offshore in small vessels and limited funding for humpback whale research has precluded data collection in offshore waters in the GOA.
Historic whaling data have shown that the offshore waters off the GOA were used extensively by humpback whales, as well as other large whale species (Townsend 1935, Nishiwaki 1966, Ivashin \& Rovnin 1967, Reeves et al. 1985, Springer et al. 2006, Ivashchenko et al. 2007). Fishermen also report humpback whales present offshore in the GOA (J. Straley and B. Witteveen pers. comm.). It is unknown how the whales present in offshore waters fit into regional feeding aggregations or the 3 management stocks in US waters within the North Pacific Ocean. Further, there is no information about the prey populations targeted by these whales.

Between 2004 and 2006, a large-scale, North Pacificwide collaborative project, entitled Structure of Populations, Levels of Abundance, and Status of Humpbacks (SPLASH), provided funding and platforms to collect humpback whale data in both inshore coastal and offshore regions of the GOA. Using identification photographs and biopsy tissue samples provided by SPLASH, we explored the movements, mitochondrial DNA (mtDNA) haplotypes, and trophic levels of humpback whales within 3 areas of the GOA to determine whether inshore and offshore feeding aggregations are distinct from one another. Results from this study contribute to our understanding of population structure, including defining feeding aggregations, for purposes of conservation and management.

\section{MATERIALS AND METHODS}

Study area. Humpback whales belonging to the central North Pacific stock located within the eastern and central GOA were the focus of this study. The GOA study area was separated into 3 regions to determine whether inshore and offshore aggregations within these regions were distinct from one another. Regions within the GOA were the Kodiak Archipelago (KOD); Prince William Sound, Kenai Fjords, and lower Cook Inlet (PWS); and southeastern Alaska (SEAK; Fig. 1). Each region was divided into inshore and offshore subregions, to create a total of 6 subregions (KODIN, KODOFF, PWSIN, PWSOFF, SEAKIN, and SEAKOFF) for comparison. Regions were defined based on the boundaries of long-term coastal inshore research efforts within each region. The inshore designation stemmed from study areas accessible by regional researchers who live in coastal communities and can conduct research from small skiffs or vessels under $10 \mathrm{~m}$. Hence, inshore animals were sighted or sampled within areas consistently covered by long-term coastal research efforts, while offshore animals were sighted or sampled from SPLASH ship-based efforts in areas not covered by the long-term inshore studies. 


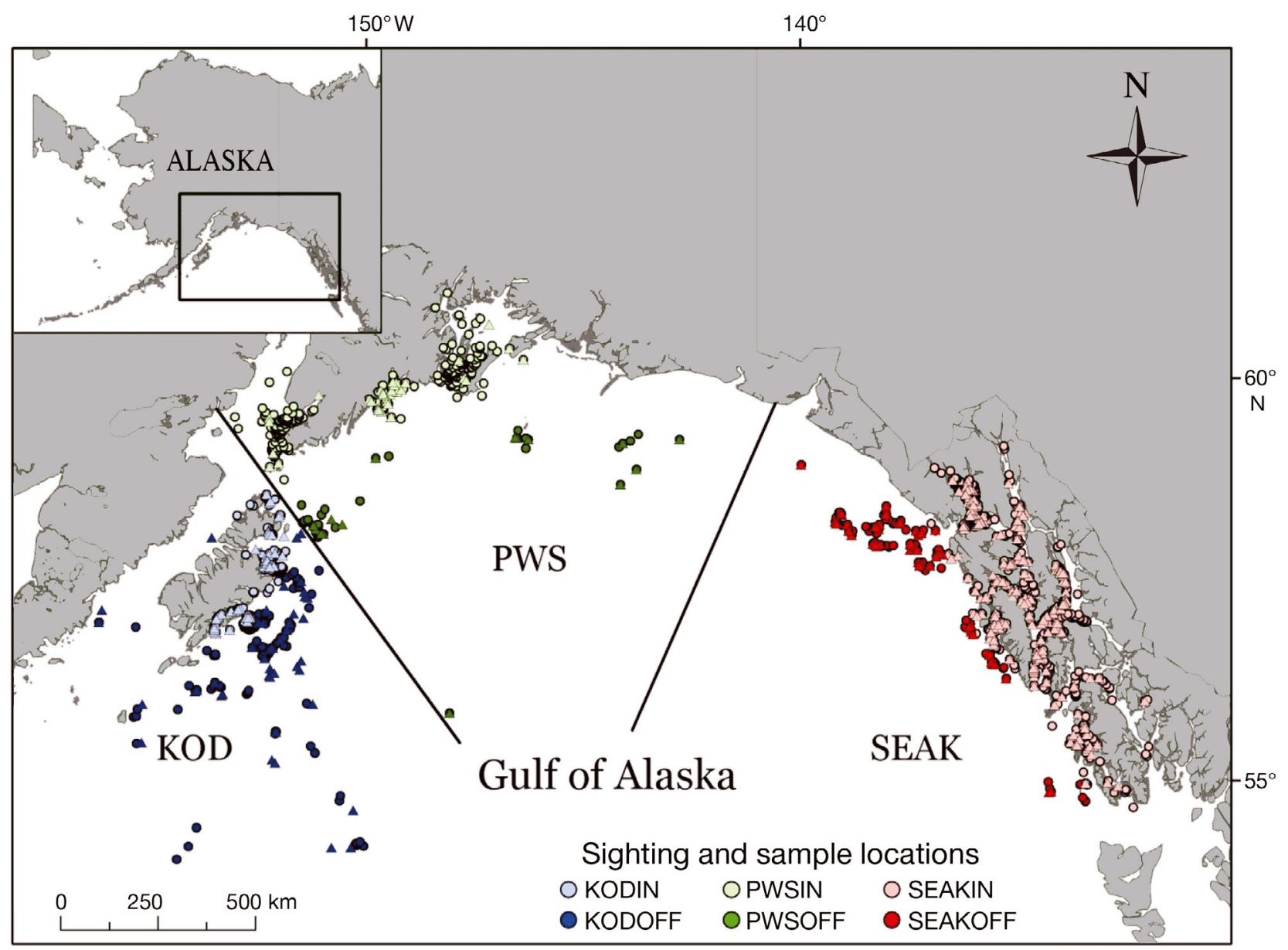

Fig. 1. Gulf of Alaska showing the separation of the 3 study regions (KOD, PWS, and SEAK). Locations of humpback whale sightings (circles) and biopsy samples (triangles) are also shown. KOD: Kodiak Archipelago; PWS: Prince William Sound, Kenai Fjords, and lower Cook Inlet; SEAK: southeastern Alaska. Suffixes IN and OFF indicate inshore and offshore subregions, respectively

Data collection. Three methodologies were used to determine whether whales present in the GOA subregions were distinct: (1) sightings of individual humpback whales documenting movement between inshore and offshore subregions and regions, (2) genetic analyses of biopsy skin samples to determine mtDNA haplotypes and sex, and (3) relative trophic levels as determined by $\delta^{15} \mathrm{~N}$ of biopsy skin samples.

Identification photographs of the flukes of individual humpback whales were collected during SPLASH surveys conducted during the feeding season (May through December) in 2004 and 2005 (Calambokidis et al. 2008).

Skin samples ( $\mathrm{n}=785$; Table 1 ) were obtained during these same surveys using a stainless steel dart and either a modified crossbow or pneumatic rifle. For each sighting, the date, position (latitude and longitude), behavior, and age class and reproductive status, if known (e.g. mother, calf), were recorded. In 2 cases where both a mother and calf were biopsy sampled, the calf was excluded from analysis because of the lack of independence of these samples. Inshore PWS sample size was supplemented with 34 samples collected by C.S.B. and O.v.Z. in 2002, to increase the sample size for this subregion. Sampling effort in the offshore subregions was substantially reduced in 2005 due to limited availability of the larger vessels that conducted surveys in 2004.

A subset of samples was analyzed for sex $(n=566)$ and mtDNA haplotype $(\mathrm{n}=483)$. In addition, sex data from SPLASH analysis were supplemented with known sexes of individuals from regional KOD, PWS, and SEAK databases based on field observations or previous genetic analyses (Table 1).

Movement. If inshore and offshore waters represent distinct feeding stocks, movement of individual animals between these areas should be uncommon. To determine whether a rate of movement between 2 subregions is low, it is useful to compare the number of documented movements between all subregion pairs as well as the number of animals resighted within a subregion. However, the highly variable number of 
Table 1. Megaptera novaeangliae. Sample sizes of humpback whales for each analysis type by region and subregion. TL: trophic level. See Fig. 1 for definitions of region abbreviations

\begin{tabular}{|c|c|c|c|c|c|c|}
\hline Region & Subregion & Individuals $^{\mathrm{a}}$ & Skin samples & mtDNA & $\mathrm{TL}$ & Sex \\
\hline \multirow[t]{3}{*}{ KOD } & Inshore & 476 & 142 & 67 & 84 & 71 \\
\hline & Offshore & 275 & 113 & 108 & 63 & 109 \\
\hline & Total & 751 & 255 & 175 & 147 & 180 \\
\hline \multirow[t]{3}{*}{ PWS } & Inshore & 315 & 94 & 80 & 42 & 76 \\
\hline & Offshore & 65 & 17 & 15 & 10 & 16 \\
\hline & Total & 380 & 111 & 95 & 52 & 92 \\
\hline \multirow[t]{3}{*}{ SEAK } & Inshore & 985 & 343 & 150 & 191 & 229 \\
\hline & Offshore & 152 & 76 & 63 & 38 & 65 \\
\hline & Total & 1137 & 419 & 213 & 229 & 294 \\
\hline Grand total & & 2136 & 785 & 483 & 428 & 566 \\
\hline
\end{tabular}

whales identified in each subregion makes this comparison difficult. To control for this difference in sample size, an index that weights the number of movements or resights based on the total number of whales identified in those subregions was applied. The index was modified from previous studies (Baker et al. 1986, Calambokidis et al. 2001, Garrigue et al. 2002). An index value of 0 indicates no documented movements between the 2 subregions. Greater index values represent a greater rate of movement between the 2 subregions being assessed, or a greater rate of resighting the same individual within a subregion. Only movements between subregions and resights within subregions that occurred between 2004 and 2005, not within a given year, were compared. This method eliminates the possibility of counting the same whale in the same location $1 \mathrm{~d}$ later as a resight. The index for resights within the same subregion starts with a ratio: the number of whales sighted in both 2004 and 2005 ( $\left.n_{04 \_05}\right)$ divided by the total number of whales sighted in 2004 $\left(n_{04}\right)$. The variable $n_{04}$ can be thought of as the number of whales available to be resighted. The ratio is then multiplied by the maximum number of whales identified in any subregion in a single year within the index comparison (equal to 679 from SEAKIN) divided by the total number of whales identified in $2005\left(n_{05}\right)$. The variable $n_{05}$ can be thought of as the number of opportunities for resighting the whales in $n_{04}$. Therefore, this index can be described as the proportion of whales available for resight that were resighted multiplied by the unlikeliness of documenting the move or resight in this subregion relative to other subregions.

The inter-annual index for resights within a subregion was calculated as

$$
i=\frac{n_{04 \_05} \times 679}{n_{04} \times n_{05}}
$$

where $n_{04 \_05}=$ number of individual whales identified in both 2004 and 2005 in the same subregion; $n_{04}=$ total number of individual whales identified in the subregion in $2004 ; n_{05}=$ total number of individual whales identified in the subregion in $2005 ; 679=$ maximum number of whales identified in a subregion during a single year.

Creating an index for inter-annual movements between subregions is more complex because this could happen in 2 ways. A whale sighted in subregion A during 2004 could be resighted in subregion B in 2005, or a whale in subregion B in 2004 could be resighted in region A during 2005. To make this comparable to inter-annual resights within a subregion, indices were calculated for both of these options, added together, and divided by 2 .

The inter-annual index for movements between subregions $\mathrm{A}$ and $\mathrm{B}$ was calculated as

$$
i=\frac{\frac{n_{\mathrm{A} 04 \mathrm{~B} 05} \times 679}{n_{\mathrm{A} 04} \times n_{\mathrm{B} 05}}+\frac{n_{\mathrm{B} 04 \mathrm{~A} 05} \times 679}{n_{\mathrm{B} 04} \times n_{\mathrm{A} 05}}}{2}
$$

Trophic level. Relative trophic levels were estimated for a subset of individuals ( $\mathrm{n}=428$; Table 1 ) based on a previous analysis of $\delta^{15} \mathrm{~N}$ determined from skin samples (Witteveen 2008, 2009b). Trophic levels of individual humpback whales were calculated using the following equation:

$$
\begin{gathered}
\text { Trophic Level (TL) }=2+ \\
\left(\delta^{15} \mathrm{~N}_{\text {humpback whale }}-\delta^{15} \mathrm{~N}_{\text {primary consumer }}\right) / 2.4
\end{gathered}
$$

where 2 is the trophic position of the primary consumer and 2.4 is the average amount of $\delta^{15} \mathrm{~N}$ enrichment between trophic levels for marine mammals (Hobson et al. 1994, Post 2002). Primary consumers, such as copepods (Calanus spp.) and filter-feeding bivalves (Patinopecten caurinus), serve as surrogates for the base of regional food webs and account for regional differences in baseline $\delta^{15} \mathrm{~N}$ values (Kling et al. 1992, Cabana 
\& Rasmussen 1996, Post 2002, Matthews \& Mazumder 2005, Andrews 2010). At least 1 primary consumer from each of the 3 regions was used (Table 2).

Statistical analyses. Pairwise chi-squared analysis was used to differentiate mtDNA haplotypes and sex. Differences in trophic levels were determined through analysis of variance (ANOVA) with subsets defined through Tukey-Kramer Honestly Significant Difference (HSD) tests. Tests were performed first for regions and then for subregions. All statistics were performed with Predictive Analysis Software (PASW) 18.0 for Windows (SPSS) with $\alpha=0.05$. All means are presented \pm SE unless otherwise noted.

\section{RESULTS}

\section{Sightings and movement}

In total, 4594 humpback whale sightings of 2136 individuals were documented within the 6 subregions during SPLASH surveys. Of these, 3913 were in the inshore habitat, while 681 were offshore. No whale was sighted in more than 2 subregions. Index values indicated that for all subregions, whales were much more likely to be resighted in the same subregion the following year than in any other subregion. When movements between subregions did occur, they were most common between adjacent inshore and offshore habitats within KOD and SEAK and between PWS and KOD inshore subregions For KOD, 12 individuals moved interannually between inshore and offshore for a movement index of 0.16 (Table 3). The movement index within SEAK was 0.22, accounting for the 6 individuals that moved between inshore and offshore. In PWS, fewer individuals moved between subregions (n $=3$ ), but the movement index was larger $(i=0.75)$. The greatest number of individuals ( $\mathrm{n}=22, i=0.16)$ moving between subregions was between PWSIN and KODIN, but the greatest index value was between SEAKOFF and PWSIN ( $\mathrm{n}=2, i=0.64$; Table 3 )

\section{Sex}

A ratio of 1.1:1 was determined for all samples analyzed for sex, with 292 males and 274 females. Most sex ratios were at or near 1:1 (Table 4). Both KOD subregions exhibited a higher proportion of males $(n=63$ OFF, $\mathrm{n}=40 \mathrm{IN}$ ) than females ( $\mathrm{n}=46 \mathrm{OFF}, \mathrm{n}=31 \mathrm{IN}$ ) for sex ratios of 1.3 and 1.4 for offshore and inshore, respectively. However, these ratios did not significantly differ from a $1: 1$ ratio $\left(\chi^{2}=2.7, p=0.10\right.$ OFF; $\chi^{2}$ $=1.1, \mathrm{p}=0.29 \mathrm{IN})$.

Table 2. Megaptera novaeangliae. Mean \pm SE values of stable nitrogen isotope ratios $\left(\delta^{15} \mathrm{~N}\right)$ for humpback whale skin $($ Witteveen et al. 2009b). Also shown are mean $\pm \mathrm{SE} \delta^{15} \mathrm{~N}$ values for primary consumers used to estimate relative trophic levels of humpback whales. See Fig. 1 for definitions of region abbreviations

\begin{tabular}{|c|c|c|c|c|c|c|c|}
\hline \multirow{2}{*}{ Region } & \multirow{2}{*}{ Subregion } & \multicolumn{2}{|c|}{ Humpback whales } & \multirow[b]{2}{*}{$\mathrm{n}$} & \multirow[b]{2}{*}{$\delta^{15} \mathrm{~N}$} & \multirow{2}{*}{$\begin{array}{l}\text { Primary consumers } \\
\text { Species }\end{array}$} & \multirow[b]{2}{*}{ Source } \\
\hline & & $\mathrm{n}$ & $\delta^{15} \mathrm{~N}$ & & & & \\
\hline \multirow[t]{3}{*}{ KOD } & Inshore & 84 & $13.4 \pm 0.10$ & \multirow[t]{3}{*}{16} & \multirow[t]{3}{*}{$8.9 \pm 0.09$} & \multirow[t]{3}{*}{ Calanus spp., Patinopecten caurinus } & Hirons (2001), \\
\hline & Offshore & 63 & $13.1 \pm 0.12$ & & & & Andrews (2010) \\
\hline & All & 147 & $13.3 \pm 0.08$ & & & & \\
\hline \multirow[t]{3}{*}{ PWS } & Inshore & 42 & $14.6 \pm 0.13$ & \multirow[t]{3}{*}{55} & \multirow[t]{3}{*}{$8.6 \pm 0.04$} & \multirow[t]{3}{*}{ Calanus spp., Patinopecten caurinus } & Hirons (2001), \\
\hline & Offshore & 10 & $13.1 \pm 0.27$ & & & & Andrews (2010) \\
\hline & All & 52 & $14.3 \pm 0.14$ & & & & \\
\hline \multirow[t]{3}{*}{ SEAK } & Inshore & 191 & $12.8 \pm 0.07$ & \multirow[t]{3}{*}{10} & \multirow[t]{3}{*}{$9.3 \pm 0.10$} & \multirow[t]{3}{*}{ Patinopecten caurinus } & \multirow[t]{3}{*}{ Andrews (2010) } \\
\hline & Offshore & 38 & $12.6 \pm 0.14$ & & & & \\
\hline & All & 229 & $12.7 \pm 0.06$ & & & & \\
\hline
\end{tabular}

Table 3. Megaptera novaeangliae. Index of inter-annual movements of individually identified whales. Bold values on the diagonal indicate the number of individual whales sighted in the same subregion in both 2004 and 2005. Index values are weighted for the difference in sample size. The number of movements is indicated in parentheses. See Fig. 1 for definitions of region abbreviations

\begin{tabular}{|c|c|c|c|c|c|c|c|c|}
\hline & 2004 (n) & 2005 (n) & KODIN & KODOFF & PWSIN & PWSOFF & SEAKIN & SEAKOFF \\
\hline KODIN & 287 & 222 & $0.35(33)$ & $0.16(12)$ & $0.16(22)$ & $0.02(1)$ & 0 & $0.24(1)$ \\
\hline KODOFF & 209 & 72 & & $0.27(6)$ & $0.03(2)$ & 0.18 (1) & 0 & 0 \\
\hline PWSIN & 224 & 154 & & & $1.24(63)$ & $0.75(3)$ & $0.01(2)$ & $0.64(2)$ \\
\hline PWSOFF & 59 & 9 & & & & $3.84(3)$ & 0 & 0 \\
\hline SEAKIN & 679 & 478 & & & & & $0.51(172)$ & $0.22(6)$ \\
\hline SEAKOFF & 148 & 5 & & & & & & 0.92 (1) \\
\hline
\end{tabular}


Table 4. Megaptera novaeangliae. Total numbers of male and female humpback whales for each region and habitat. Also shown is the male to female sex ratio. See Fig. 1 for definitions of region abbreviations

\begin{tabular}{|lcccc|}
\hline \multirow{2}{*}{ Region } & Habitat & Male & Female & M:F \\
\hline KOD & Inshore & 40 & 31 & 1.3 \\
& Offshore & 63 & 46 & 1.4 \\
& Total & 103 & 77 & 1.3 \\
PWS & Inshore & 34 & 42 & 0.8 \\
& Offshore & 6 & 10 & 0.6 \\
& Total & 40 & 52 & 0.8 \\
SEAK & Inshore & 116 & 113 & 1.0 \\
& Offshore & 33 & 32 & 1.0 \\
& Total & 149 & 145 & 1.0 \\
Sex total & & 292 & 274 & 1.1 \\
Grand total & & & 566 & \\
\hline
\end{tabular}

\section{mtDNA haplotypes}

GOA humpback whales were represented by 15 mtDNA haplotypes. KODOFF showed the most diversity in haplotypes, with 11 of 15 represented, while SEAKOFF showed the least diversity with only 4 (Fig. 2). The A- and A+ haplotypes were the most dominant haplotypes for all subregions. Regions were significantly different from one another in chi-squared tests of independence (KOD versus PWS: $\chi^{2}=47.0$, $\mathrm{p}<0.001$; KOD versus SEAK: $\chi^{2}=118.1, \mathrm{p}<0.001$; PWS versus SEAK: $\left.\chi^{2}=102.4, \mathrm{p}<0.001\right)$. Following significant results of regional comparisons, chi-squared tests were performed to compare subregions. Results showed that the frequencies of haplotypes differed significantly between 11 of the 15 pairwise comparisons of subregions. Pairwise comparisons were not significant for KODIN versus $\operatorname{KODOFF}\left(\chi^{2}=8.5, \mathrm{p}=0.67\right)$,
KODIN versus PWSOFF $\left(\chi^{2}=3.2, \mathrm{p}=0.92\right)$, KODOFF versus PWSOFF $\left(\chi^{2}=4.2, \mathrm{p}=0.84\right)$, and SEAKIN versus SEAKOFF $\left(\chi^{2}=3.3, p=0.51\right)$. PWSIN was the only subregion that was significantly different in haplotypes from all other subregions (Table 5).

\section{Trophic levels}

The mean trophic level for all subregions combined was $3.7 \pm 0.02$. Means ranged from a high of $4.5 \pm$ 0.05 for PWSIN to a low of $3.4 \pm 0.06$ for SEAKOFF (Fig. 3). ANOVA showed that trophic level varied significantly as a function of region $(F=131.6, \mathrm{p}<0.001)$ and then by subregion $(F=59.3, \mathrm{p}<0.001)$. Tukey HSD subsets grouped the SEAK subregions together, KOD subregions with PWSOFF, and PWSIN in its own subset (Fig. 3).

\section{DISCUSSION}

We used comparative analysis from 3 methodologies to explore connections and differences between whales foraging offshore and inshore in the Gulf of Alaska. Results provide strong support for subregions

Table 5. Megaptera novaeangliae. Results of pairwise chisquared comparisons of haplotype frequencies between each of the 6 subregions in the Gulf of Alaska. ${ }^{*} p<0.05,{ }^{* *} p<0.001$. See Fig. 1 for definitions of region abbreviations

\begin{tabular}{|c|c|c|c|c|c|}
\hline & KODOFF & PWSIN & PWSOFF & SEAKIN & SEAKOFF \\
\hline KODIN & 8.45 & $30.52^{* *}$ & 4.22 & $64.04^{* *}$ & $37.41^{* *}$ \\
\hline KODOFF & & $39.29^{* *}$ & 6.52 & $82.57^{* *}$ & $52.62^{* *}$ \\
\hline PWSIN & & & $12.19^{*}$ & $80.09^{* *}$ & $49.02^{* *}$ \\
\hline PWSOFF & & & & $33.41^{* *}$ & $18.50^{*}$ \\
\hline SEAKIN & & & & & 3.30 \\
\hline
\end{tabular}
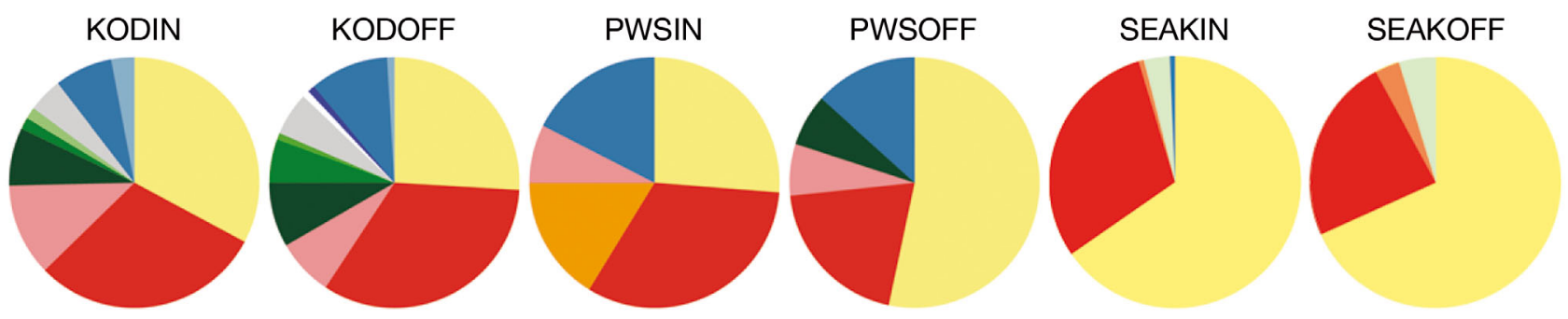

HAPLOTYPE

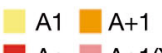

$A+\square+1(X 8)$

$A X 7$

$\mathrm{E} 1+\mathrm{A}$

$\mathrm{E} 1+\mathrm{CT} \quad \mathrm{E} 3+\mathrm{C}$

$\mathrm{E} 1+\mathrm{C} 3 \quad \mathrm{E} 2 \quad \square \mathrm{E} 3+\mathrm{C} 1 \quad \mathrm{~F} 2+\mathrm{C}$
F2-C

Fig. 2. Megaptera novaeangliae. Composition of mtDNA haplotype frequencies and sample sizes for humpback whales within each of the 6 subregions. See Fig. 1 for definitions of region abbreviations 


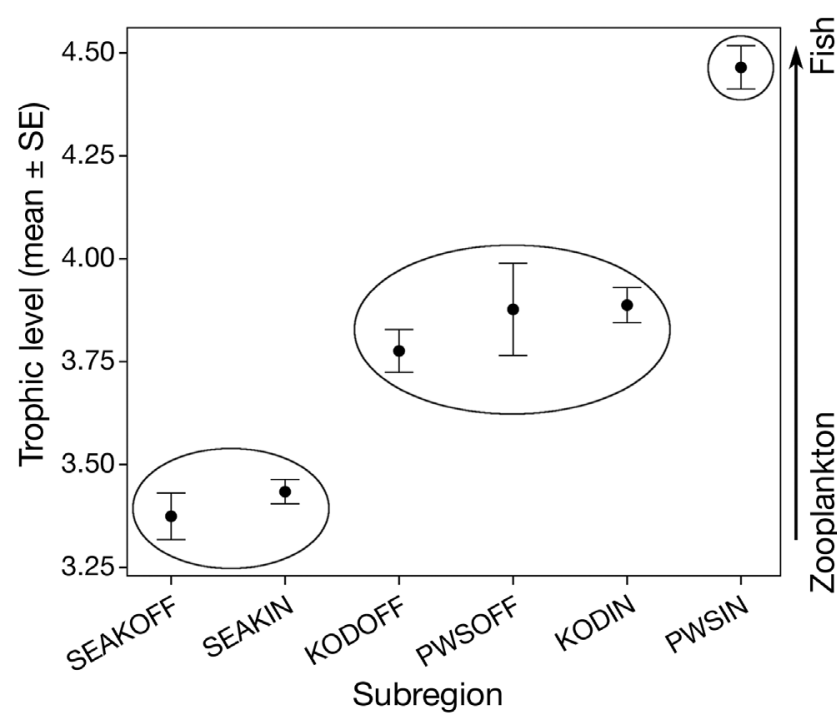

Fig. 3. Megaptera novaeangliae. Mean $( \pm \mathrm{SE})$ trophic levels of humpback whales estimated from $\delta^{15} \mathrm{~N}$ for each of the 6 subregions in the Gulf of Alaska. The arrow on the secondary $y$ axis reflects the transition from zooplankton to fish diets with increasing trophic level. Ellipses indicate groups with similar means as shown by Tukey HSD post hoc comparisons. See

Fig. 1 for definitions of region abbreviations

to be considered as single feeding aggregations within their respective regions for KOD and SEAK, but patterns are less clear for subregions within PWS.

Resights were generally greatest within subregions (i.e. SEAKIN to SEAKIN) and between subregions within the same region (i.e. SEAKIN to SEAKOFF). This result supports the fidelity to feeding grounds previously documented for humpback whales (Baker et al. 1986, Straley et al. 1994, Calambokidis et al. 1997, 2008, Waite et al. 1999, Witteveen et al. 2007). The PWS subregions showed higher within-subregion movement indices, suggesting either smaller populations or higher site fidelity in these subregions. Somewhat confounding this result is the fact that the largest amount of movement between subregions was between PWSIN and KODIN. While the actual number of individuals that showed this movement was high relative to other subregion pairings, a comparison of index values showed that this movement was less prominent than resights within subregions and on par with indices from other subregion pairs. When looking at total movement numbers, both inter- and intra-annually, only 13 of 47 movements from the PWSIN subregion were from Prince William Sound proper. Most movements occurred between lower Cook Inlet and the Barren Islands and waters adjacent to northeast Kodiak Island (Fig. 4). A possible explanation is that a small core group of animals remains within Prince William Sound, while animals utilizing other grounds within what was defined as PWSIN are more prone to movement in the central Gulf of Alaska.

While the Gulf of Alaska showed considerable haplotype diversity as a whole, diversity increased from east to west, with the SEAK subregions dominated by only 2 haplotypes (A- and $\mathrm{A}+$ ) and the KOD subregions represented by 11 haplotypes. Comparisons revealed that the subregions of SEAK were significantly different than all other subregions. SEAK is unique in having only 2 primary haplotypes and emphasizes how genetic distinctiveness creates separate feeding aggregations which can be vulnerable to human activities.

Mean trophic levels suggest that humpback whales in the Gulf of Alaska feed on a mixed fish and zooplankton diet and that no subregion is dependent on a strictly zooplankton diet, as planktivorous cetaceans tend to have much lower trophic levels (TL 2.8 to 3.0; Hoekstra et al. 2002). Significant differences in trophic levels, however, do suggest differences in diet composition between subregions. The lower levels found in the SEAK subregions suggest a diet higher in zooplankton and lower in fish

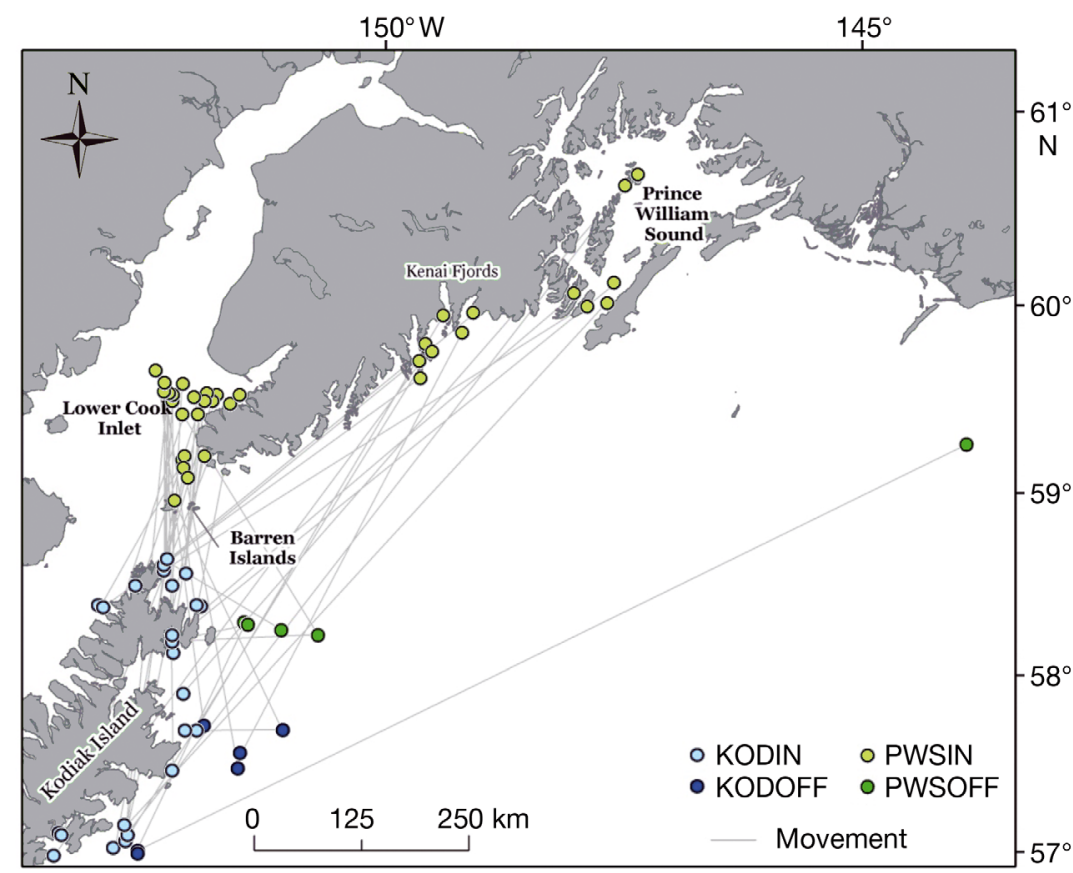

Fig. 4. Megaptera novaeangliae. Movements of individual humpback whales between PWS and the KOD regions. See Fig. 1 for definitions of region abbreviations 
species, while the opposite is likely true in the KOD subregions and PWSOFF. The high trophic level of PWSIN is indicative of a diet comprised almost exclusively of fish (TL 4.4 to 4.8 ; Lesage et al. 2001).

All regions in this study are assigned to the central North Pacific stock of humpback whales, yet the SEAK region was clearly different from the other regions with respect to stable isotope ratios, genetics, and movement patterns. These results argue that the definition of the central North Pacific stock may need to be reconsidered. Results also suggest that the PWSIN subregion may be unique among all subregions within the central North Pacific stock. The PWSIN subregion was the only one to be significantly different from all other subregions based on mtDNA and trophic level comparisons. In addition, there was a much smaller rate of movement between inshore and offshore habitats within the PWS region than in KOD or SEAK. There were, however, a large number of documented movements between PWSIN and KODIN, which may be explained by a definition of the boundary that separated KOD and PWS (see 'Study area' in 'Materials and methods' and 'Discussion' above). Further, it is likely that a whale from KOD may travel through the waters of the PWS region while transiting to or from the southern breeding area during migration. Interestingly, most movements between KOD and PWSIN documented by photo-identification originated from lower Cook Inlet, but most tissue samples were collected from Prince William Sound proper. This suggests that Prince William Sound may itself represent a distinct feeding aggregation of humpback whales with specialized prey preferences. A distinct feeding aggregation in Prince William Sound could have significant implications for resource allocation and for regional prey populations, including the depleted stock of Pacific herring (Exxon Valdez Oil Spill Trustees Council 2010, www.evostc.state.ak.us/recovery/status_herring.cfm).

There are a few caveats that should be noted. First, though separation of GOA into regions was based on distribution, historic data, and personal observations, the definitions of KOD, PWS, and SEAK may not correspond precisely to biological reality. Similarly, the designation of inshore and offshore habitats was based on research effort and not any oceanographic or biological factors. It may be that these habitats are defined by different characteristics between regions. Second, in a few cases $(n=25)$, samples were collected from individuals where an identification photograph was not obtained, which may have resulted in an unknown duplicate sampling of the same animal. Clearly, if this occurred to a high degree, our results would be impacted. However, due to the relatively large number of samples, we do not believe this to be a significant issue here. Finally, effort was concentrated in the traditional summer feed- ing months (May through September), but humpback whales can be found in higher latitudes year round (Straley 1994, Wynne \& Witteveen 2005). Therefore, the results presented here represent movements of individuals within what may be only a portion of time spent in the GOA. Further investigation is needed to refine the geographical boundaries and seasonality of feeding aggregations to maximize the delineation of each region in terms of genetic structure, feeding ecology, and site fidelity over what is likely to be a biological gradient. Specifically, in areas of low sample size (e.g. PWSOFF) and transition areas (e.g. Lower Cook Inlet), increased sampling effort would provide additional data and insight to clarify distinctions.

This study reinforced that humpback whale feeding aggregations maintain high site fidelity and are distinct genetically, as well as trophically. Results suggest that the inshore and offshore habitats of KOD and SEAK should be considered together, but that PWS habitats be considered distinct from one another. Combining methodologies proved to be a powerful tool in refining knowledge of population structure of humpback whales in the GOA. An accurate understanding of the structure of the humpback whale population is fundamental for a variety of management concerns, including evaluating the impact of ship strikes, fishing interactions, and catastrophic events. It is also necessary to evaluate their status under the US Endangered Species Act. Application of these methods to other regions and species could provide similar refinement of boundaries and assist in determining the locations of unique aggregations for use in conservation and management.

Acknowledgements. We are grateful to the SPLASH steering committee and the large list of SPLASH participants who contributed data used in this study and to the SPLASH project as a whole. In particular, we thank E. Falcone of Cascadia Research Collective and K. Robertson from NMFS Southwest Fisheries Science Center for their invaluable assistance with database and sampling archives. We also thank J. Calamobokidis of Cascadia Research for leading the photographic matching efforts. Thank you to the SEAK regional database manager, J. Cedarleaf. We thank 2 anonymous reviewers for their edits and suggestions which greatly improved this manuscript. All research was conducted under NOAA scientific research permits issued to and managed by individual agencies.

\section{LITERATURE CITED}

Allen BM, Angliss RP (2010) Alaska marine mammal stock assessments, 2009. NOAA Tech Memo NMFS-AFSC-206. US Dept Commerce, Seattle, WA

Andrews AG III (2010) Variation in the trophic position of spiny dogfish (Squalus acanthias) in the northeastern Pacific Ocean: an approach using carbon and nitrogen stable isotopes. $\mathrm{PhD}$ dissertation, University of Alaska Fairbanks, Fairbanks, AK 
Baker CS, Herman LM, Perry A, Lawton WS and others (1986) Migratory movement and population structure of humpback whales (Megaptera novaeangliae) in the central and eastern North Pacific. Mar Ecol Prog Ser 31:105-119

- Baker CS, Palumbi SR, Lambertsen RH, Weinrich MT, Calambokidis J, O'Brien SJ (1990) Influence of seasonal migration on geographic distribution of mitochondrial DNA haplotypes in humpback whales. Nature 344: 238-240

Baker CS, Medrano-Gonzalez L, Calambokidis J, Perry A and others (1998) Population structure of nuclear and mitochondrial DNA variation among humpback whales in the North Pacific. Mol Ecol 7:695-707

> Cabana G, Rasmussen JB (1996) Comparison of aquatic food chains using nitrogen isotopes. Proc Natl Acad Sci USA 93:10844-10847

Calambokidis J, Steiger GH, Straley J, Quinn TJ II and others (1997) Abundance and population structure of humpback whales in the North Pacific Basin. Report to Southwest Fisheries Science Center, National Marine Fisheries Service, La Jolla, CA

Calambokidis J, Steiger GH, Straley JM, Herman LM and others (2001) Movements and population structure of humpback whales in the North Pacific. Mar Mamm Sci 17: 769-794

Calambokidis J, Falcone EA, Quinn TJ II, Burdin AM and others (2008) SPLASH: Structure of Populations, Levels of Abundance and Status of Humpback whales in the North Pacific. Final report for contract AB133F-03-RP-00078 for US Dept Commerce Western Administrative Center, Seattle, WA

Garrigue C, Aguayo LA, Amante-Helweg VLU, Baker CS and others (2002) Movements of humpback whales in Oceania, South Pacific. J Cetacean Res Manag 4:255-260

Hobson KA, Piatt JF, Pitocchelli J (1994) Using stable isotopes to determine seabird trophic relationships. J Anim Ecol 63:786-798

Hoekstra PF, Dehn LA, George JC, Solomon KR, Muir DCG, O'Hara TM (2002) Trophic ecology of bowhead whales (Balaena mysticetus) compared with that of other Arctic marine biota as interpreted from carbon-, nitrogen-, and sulfur-isotope signatures. Can J Zool 80:223-231

Ivashchenko YV, Clapham PJ, Brownell RL Jr (eds) (2007) Scientific reports of Soviet whaling expeditions, 19551978. NOAA Tech Memo NMFS-AFSC-175, US Dept Commerce, Seattle, WA

Ivashin MV, Rovnin AA (1967) Some results of the Soviet whale marking in the waters of the North Pacific. Norsk Hvalfangst-Tidende 57:123-135

Kling GW, Fry B, O'Brien WJ (1992) Stable isotopes and planktonic trophic structure in arctic lakes. Ecology 73:561-566

> Lesage V, Hammill MO, Kovacs KM (2001) Marine mammals and the community structure of the Estuary and Gulf of St Lawrence, Canada: evidence from stable isotope analysis. Mar Ecol Prog Ser 210:203-221

Matthews B, Mazumder A (2005) Temporal variation in body composition $(\mathrm{C}: \mathrm{N})$ helps explain seasonal patterns of zooplankton $\delta^{13} \mathrm{C}$. Freshw Biol 50:502-515

Nishiwaki M (1966) Distribution and migration of the larger cetaceans in the North Pacific as shown by Japanese whaling records. In: Norris KS (ed) Whales, dolphins, and porpoises. University of California Press, Berkeley, CA, p 172-191

Post DM (2002) Using stable isotopes to estimate trophic position: models, methods, and assumptions. Ecology 83: 703-720

Reeves RR, Leatherwood S, Karl SA, Yohe ER (1985) Whaling results at Akutan (1912-39) and Port Hobron (1926-37), Alaska. Rep Int Whal Comm 35:441-457

Springer A, van Vliet GB, Piatt JF, Danner EM (2006). Whales and whaling in the North Pacific Ocean and Being Sea. In: Estes JA, Brownell RL Jr, DeMaster DP, Doak DF, Williams TM (eds) Whales, whaling and ocean ecosystems. University of California Press, Berkeley, CA, p 245-261

Straley JM (1994) Seasonal characteristics of humpback whales (Megaptera novaeangliae) in southeastern Alaska. MSc thesis, University of Alaska Fairbanks

> Straley JM, Gabriele CM, Baker CS (1994) Annual reproduction by individually identified humpback whales (Megaptera novaeangliae) in Alaskan waters. Mar Mamm Sci 10:87-92

Straley J, Quinn TJ II, Gabriele CM (2002) Estimate of the abundance of humpback whales in Southeastern Alaska 1994 to 2000. National Marine Fisheries Service National Marine Mammal Laboratory, Seattle, WA

Straley J, Quinn TJ II, Gabriele CM (2009) Assessment of mark-recapture models to estimate the abundance of a humpback whale feeding aggregation in Southeast Alaska. J Biogeogr 36:427-438

Townsend $\mathrm{CH}$ (1935) The distribution of certain whales as shown by logbook records of American whaleships. Zoologica 19:1-50

von Ziegesar O, Goodwin B, DeVito R (2001) A catalog of humpback whales in Prince William Sound, Alaska 1977 to 2001. Eye of the Whale Research, Homer, AK

- Waite JM, Dahlheim ME, Hobbs RC, Mizroch SA and others (1999) Evidence of a feeding aggregation of humpback whales (Megaptera novaeangliae) around Kodiak Island, Alaska. Mar Mamm Sci 15:210-220

Witteveen BH (2008) Using stable isotopes to assess population structure and feeding ecology of North Pacific humpback whales (Megapatera novaeangliae). PhD dissertation, University of Central Florida, Orlando, FL

Witteveen BH, Straley JM, von Ziegesar O, Steel D, Baker CS (2004) Abundance and mtDNA differentiation of humpback whales (Megaptera novaeangliae) in the Shumagin Islands, Alaska. Can J Zool 82:1352-1359

Witteveen BH, Wynne KM, Quinn TJ II (2007) A feeding aggregation of humpback whales near Kodiak Island, Alaska: current and historic abundance estimation. Alsk Fish Res Bull 12:187-196

- Witteveen BH, Foy RJ, Wynne KM, Tremblay Y (2008) Investigation of foraging habits and prey preference of humpback whales (Megaptera novaeangliae) near Kodiak Island, Alaska using acoustic tags. Mar Mamm Sci 24: $516-534$

Witteveen BH, Worthy GAJ, Roth JD (2009a) Tracing migratory movements of breeding North Pacific humpback whales using stable isotope analysis. Mar Ecol Prog Ser 393:173-183

> Witteveen BH, Worthy GAJ, Wynne KM, Roth JD (2009b) Population structure of North Pacific humpback whales on their feeding grounds revealed by stable carbon and nitrogen isotope ratios. Mar Ecol Prog Ser 379:299-310

Witteveen BH, Worthy GA, Wynne K, Hirons AC, Andrews AG, Markel RW (2011) Trophic levels of North Pacific humpback whales through analysis of stable isotopes: implications on prey and resource quality. Aquat Mamm 37:101-110

Wynne K, Witteveen BH (2005) Opportunistic aerial sightings of large whales within Steller sea lion critical habitat in the Kodiak archipelago. In: Wynne K, Foy RJ, Buck CL (eds) Gulf apex predator-prey study final report FY 2001-2003. University of Alaska Fairbanks, Kodiak, AK, p 105-119 